\title{
DEFIANT MEMORY AND THE INFRASTRUCTURE OF INTIMACY: THE THRIVING HOMES OF MĀORI JEWS IN AOTEAROA, NEW ZEALAND
}

\author{
Hadas Ore ${ }^{1}$
}

\begin{abstract}
Social research since the 1980 s demonstrates the resurgence of interest in whakapapa and growing recognition in the importance of whanau for the affirmation of being Māori in contemporary Aotearoa, New Zealand. Analysing memories of home, this paper integrates the latest development in the theory of home and nostalgia with empirical data from social psychology on the well-being of contemporary Māori Jews. The data is based on open-end, in-depth interviews with twenty-one Mäori Jews between the ages of eighteen and sixty-seven years old, highlighting relationship with whakapapa through funerary practices and food. It demonstrates that contemporary Māori Jews express longing for home and intimacy as well as ambivalence, pain and grief as they critique home. In their lived relationships with whakapapa the Māori Jews in this study employ defiant memory to resist the intergenerational racial tension within their whänau. In this way, they constitute their infrastructure of intimacy and ameliorate their well-being.
\end{abstract}

Keywords: home; defiant memory; well-being; racial tension; intimacy.

\section{INTRODUCTION}

There's this Māori and Jewish from my mother and her mother [...] being in a totally Jewish group sometimes [...] I know I'm Jewish [but] maybe I am not Jewish as they are? Or amongst Māori - I am not as Māori as they are? [...] And yet, when people criticise Māori, I'm Māori, or go on about Jewish, I am Jewish (sixty-two year-old Māori Jewish woman).

My initial step toward the study of twenty-one Mãori Jews and their memories of home was inadvertent. In the course of my PhD fieldwork during the early 
2000 s in Aotearoa, New Zealand, I met two Jewish-Israeli migrant women who married Māori men. As a Jewish-Israeli migrant woman myself, an air of silence drew me to look into the relationship between Jewish people and the indigenous people of Aotearoa, New Zealand. During what became my postdoctoral research project, I was struck by the racism Māori Jews encountered and recalled, i.e. the prejudiced feelings and attitudes that are based upon signifiers of their Otherness such as skin colour and facial features.

The opening quote illustrates that the dialectic tension of remembering whakapapa from mixed cultural affiliations stirs ambivalence for those who are raised by Māori-Jewish whānau. Whakapapa is usually understood as descent lines, although Māori theorists also refer to systems of connections with stars, water, land and food - 'an epistemological framework in which perceived patterns and relationships in nature are located' (Roberts et al. 2004).

As the informant above points out, her connection with whakapapa is the main means for establishing Māori-Jewish affiliations. Most of the Māori Jews I interviewed defend these affiliations in the face of racism, specifically people who 'criticise Māori' and 'go on about Jewish', which contributes to their ambivalence. Focussing on their ambivalence, I ask how Māori Jews deal with memories of racial tension within their whānau, and the impact this has on their well-being. My analysis considers the recent theoretical development in the theory of home and nostalgia, which I integrate with empirical studies in social psychology. Most of these studies claim that racism and systemic inequalities prevent the fast-growing Māori population from making a better life in Aotearoa, New Zealand (August 2005; Came 2014; Cunningham 2008; Hippolite and Bruce 2010; Houkamau, Stronge, and Sibley 2017; Johnston and Pihama 1994; Morris 2010; Sibley et al. 2011; Pack, Tuffin, and Lyons 2017).

Thus in this paper I ask how this group of Māori deal and cope with racial tension. My investigation considers the increasing number of studies that demonstrate the contribution of the resurging interest in whakapapa and the growing recognition of the importance of whannau for the affirmation of the success and well-being of contemporary Māori in Aotearoa, New Zealand (Doerr 2015; Houkamau 2011; Tamaira 2007; Te Rito 2007; Webber 2008, 2011). My analysis builds on the literature that acknowledges variation in Māori experiences based on diversity, which derives in part from a long history of intermarriage between Māori and non-Māori (Callister 2003; Wanhalla 2009; Webber 2008). Nearly half of those who identify as Māori also affiliate with another ethnicity that is not Māori (Goodyear 2009, 12). 
I estimate that there are several thousand Māori Jews living mainly in Aotearoa, New Zealand, Israel, the United States and Australia. Historic evidence shows that intermarriage between Māori and Jews began in the early 1830s, with Jewish migrants and prominent traders Joel Samuel Polack and John (Julius) Israel Montefiore (Rose 2009; Wigglesworth 1990). It was common practice at that time for high-ranking Māori women to marry with older English JewishAshkenazi (east and central European) men, setting up prosperous and large families, such as the Asher whanau in Tauranga, and the Nathan, Montefiore and Yates whānau in Northland (Bailey 2012; Beaglehole and Levine 1995; Bell and Morrow 2012; Gluckman 1990; Puckey 2006, 2011; Rose 2009; Rosenthal 1988). By the 1870 s-189os, Jews were regarded as part of a distinct part of the colonising group of Pākehā (European descent), belonging to a separate religious denomination, the 'Hebrew church.' ${ }^{2}$ Yet from the 1940 J Jewish German refugees suffered from racial abuse and were frequently ostracised, as several of this study's informants attested to with regard to their own ancestors. Prejudice, suspicion and strict control over cultural minorities were directly expressed by the governmental policy toward Jews during the 1930s-1940s (Beaglehole 2013).

In the following, I elucidate the theoretical background for the study of Māori Jews, and examine the question of what is home for Māori? And how do they define their well-being from their perspectives as indigenous people? I then explain my methodology and describe the participants. Next I bring the analysis of interview excerpts and excerpts from my fieldnotes; these are divided into three hubs of remembering: funerals, food and racism. Funerals and food practices are merely two domains that exemplify how Mãori Jews constitute intimacy, affection and familiarity when remembering home, using these to cope with, reconcile and overcome the racial tension within their whānau. Racism exemplifies intergenerational tensions within whānau.

THE THEORY OF HOME, NOSTALGIA AND WELL-BEING

Studies that focus on the Māori population argue that racist beliefs and attitudes are internalised by Māori under the impact of the government, the education system, and the media as part of their colonisation (see for example the review by Pack, Keith, and Antonia 2016). More recent empirical studies point out that awareness of the unconscious bias in the education system and the media is required to decolonise the common racist attitudes and beliefs in the society at large (Blank, Houkamau, and Kingi 2016; Sibley, Liu, and Khan 2008).

Yet there are important variations within the Māori population revealed through studies on mixed ethnic intermarriage such as Māori Chinese (Ip 2008, 
2009), Māori Dalmatians (Bozic-Vrbancic 2004), Māori Indians (AikmanDodd 2013; Pio 2009) and Māori Pākehā (Wanhalla 2008, 2009, 2013). For example, Māori Pākehā families from southern Aotearoa, New Zealand of the Maitapapa community use 'the very act of remembering' to 'challenge a past that is entwined with state assimilation policy and community disintegration' by recalling their Māori cultural roots in oral histories and reconstructing their Māori past through photography (Wanhalla 2009, 158).

Contemporary Māori living in the city of Auckland suffer from strong nostalgia for their village life, and engage in reveries that mystify and idealise their past, an affective phenomenon that is also typical for migrants from first to third generations (Gagné 2013, 63-65). Recent development in the theory of home and nostalgia suggests that such reveries and memories of village life may be a form of contestation critiquing downward trending social conditions of particular groups in the face of rapid societal change (see also Bardenstein 2002; Battaglia 1995; Berdahl 2009; Creighton 1997; Duruz 1999; Hage 1997; Kugelmass 1990; Law 2005; McDermott 2002; Sugiman 2005). Thus both the longing for the 'home' of the past, and the pain of yearning to go back in time (and often space) point to current tensions in social relationships. In my $\mathrm{PhD}$ work (2015) I focused on the ways Jewish-Israeli women remember and reconstitute home after migrating to New Zealand. I argued that home can be imagined as a house that is divided into different rooms, each room representing a dimension that people realise through their everyday practices, memories and emotions. The 'house' is obviously not ruined or demolished by migration, but shifting to a new cultural context leads to transformations both in its exterior and in the interior design of each room representing the five main dimensions of relations: with national homelands, ancestral spaces that materialise kinship relationships between generations, communal places of belonging, 'homes' as spiritual sites, and as the personal body.

The theoretical development of 'home' perceived as a multidimensional space and nostalgic expressions of longing and critique of home is based in part on the work of Spitzer (1999), which foregrounds elements of resistance in nostalgia as defiant memory. Spitzer (1999) illustrated that Austro-German migrant Jews who settled in Bolivia during World War Two use defiant memory as acts of cultural recall that may be ritualised in everyday life. In their memories of 'back home', which materialise via Jewish festive meals and dishes, these Jews conveyed strong yearning to pre-Nazi Europe, expressing both their deep national affiliations, and their contestation of decimation by the Nazis. In these acts of recall, intimacy, affection and longing for the national homes is enmeshed with racial tensions. As Berdahl (2009) showed with regard to 
the everyday consumption of East Germans in the post-socialist 199os, their defiant memory express critique of westernisation and capitalism in the face of dramatic socio-political changes.

The idea of a dialectic tension between longing, intimacy and affection, and the critique of home that is situated at the heart of nostalgia, echoes developments in media studies and feminist philosophy that contribute to complex understanding of the politics of the familial home. The work of Berlant (1998) showed that affective paradoxes in kinship relationships form an infrastructure of intimacy' which at the same time creates public spaces. The infrastructure of intimacy that constitutes the multidimensional home is embedded in fields of material and symbolic powers between and within races, ethnicities, genders, generations, classes, nations, and so on. For example, Armove (2017) claims the infrastructure of intimacy in familial homes of Palestinians under the Israeli occupation gives rise to their 'political subjectivity, place-making, and the possibility for transformative futures' beyond the trauma of the destruction of their actual houses. Considering the racism and the long-reaching consequences of colonisation that Māori currently suffer from, what then, may we surmise regarding the memories of 'home' that Māori Jews share, and the infrastructure of intimacy evident in their memories? For the purpose of this study, I use intimacy to indicate their longing and affection, and their critique to indicate racial tension. Identifying such affective expressions reveals how they build their infrastructure of intimacy within their whānau and negotiate social relationships in their society.

\section{What is 'home' for contemporary Māori?}

As many other ethnic groups in the Pacific, the engagement of Māori with migration is not new (Leach 2010), and their circular movement between places and spaces of temporary importance challenges conceptualising home through dichotomies such as past/present and close/distant. This movement, for example, deconstructs the binary of ahi kā - the people and place of warm fire, and ahi mātao - the space of cold fire (Carter 2015), expressing fluidity that is indicated linguistically. One participant suggested that there are at least four well known terms in this regard: ahi kā - continuous occupation also known as ahi-kā-roa; ahi tahutahu - intermittent occupation, whereby customary use is maintained by limited occupation; ahi tere or ahi teretere - flickering or unstable places that whānau have not returned for three or four generations; and ahi mātao or ahi mātotao - cooling fires, where land has been abandoned, or all but abandoned. Moreover the fluidity, multiplicity and nuances of homely feelings are variously expressed in Te Reo Māori (the Māori language) as kāinga 
relates to the place where the fire has burnt, an unfortified place of residence, place of adobe, country and home (Williams 1957, 81); notions of turangawaewae are the standing place and the spiritual home; and papakainga is the territory around the marae (central tribal-communal gathering place) or land of tribal residence (Gagné 2013). Gagné rightly claims that contemporary Māori understand home as 'lived relationships, and not as distinct realities and entities' (p.85). As a multidimensional space home for contemporary Māori is constituted through lived relationships that realise five main dimensions: homelands, ancestral-familial connections, communal spaces, spiritual connections, and the personal body. In this paper I focus on the dimension of ancestral-familial connections. I segue now to the related concept of well-being.

\section{What is well-being for contemporary Māori?}

Māori maintain a highly influential distinction between personal well-being - the standard of living, health, achievements, personal relationships, safety, feeling part of a community, and future security; and national well-being - the economic situation, New Zealand's social and political environment, the state of business and national security (Houkamau and Sibley 2011). Houkamau and Sibley suggest these two dimensions of well-being reflect systemic inequalities stemming from their colonisation. In a later study these scholars point to the reverse correlation between national well-being, and personal well-being and cultural efficacy. This refers to the revival, since the 1980s, in knowledge of how to be Māori using cultural practices such as kapa haka (dance and song performative groups), Te Reo Māori and marae etiquette (Houkamau and Sibley 2016). This indicates that the social expectations of contemporary Māori are premised on group principles and identifications, rather than individual ones compared with Pākehā.

Interestingly, the articulations between personal and national well-being are supported by studies in social psychology that examine the mixed ethnicity of Māori. These show that Māori who also identify as Pākehā have improved employment outcomes, better incomes, and higher levels of education attainment compared to those who identify solely as Māori (Callister 2008; Chapple and Rea 1998). Moreover, comparing the well-being of those Māori who identify as sole-Māori with those who identify as Māori with other ethnicities, shows the latter have higher well-being (Callister 2008; Chapple and Rea 1998; Houkamau and Sibley 2014). Therefore, Houkamau and Sibley $(2014,113)$ posit that a more nuanced understanding of well-being is required, pointing out that those Māori who also identify as Pākehā score lower on various indicators of 
social and economic status, compared to those who identify solely as Pākehā, despite similarity to Pākehā in their political agenda.

Thus, 'home' is the multidimensional relationships that are realised and lived by Māori through their everyday practices. As such, it remains to be seen how home is constituted by their affective memories of longing and intimacy, as well as critique, leaving lasting impact on their well-being. In this paper I deal mainly with the dimension of ancestral and familial connections.

\section{Methodology}

My analysis is based on in-depth interviews using open-ended questions that took place over the course of nine months. I met with twenty-one Māori Jewish individuals; thirteen women and eight men. The interviews (duration of twoto-five hours) were conducted according to the participants' wishes; at their homes, cafés, the Jewish cemetery on Karangahape Road (Auckland Central), and via electronic communication (Skype).

I learned Te Reo Māori during two semesters in Auckland University of Technology to increase my understanding of whakapapa and other important Māori organising principles and ideas, and to better communicate with my informants, nine of whom are fluent in Te Reo Māori. However, the interviews took place in English for the convenience of both sides with many words, terms, phrases and concepts being communicated to me in Te Reo Māori.

I began every interview with signing the consent form officially and asking permission to record the interview. I reminded the interviewees that anything they said could become off-record upon their request. I would then ask for personal details or a short demographic profile regarding their age, profession, education, familial status and place of residence. Then I asked about where they grew up and their memories of home and childhood. Usually, I would finish the conversation by asking the participant to define 'home' and explain where they felt 'at home'. At the end of each interview I asked participants to describe their well-being, and to grade it from one to ten, with ten being the best state. Nearly all the participants chose seven or eight to indicate the grade of their current well-being, thus, expressing relatively high well-being. This is consistent with Houkamau and Sibley's (2011) findings on the impact of multiple ethnic affiliations for Māori, compared to single affiliation. In addition, I often received photos and clarifications regarding names, dates and locations from participants via email that supported the stories they told me. 


\section{The Participants}

All the participants in this study were strangers to me prior to the study. Our initial connections were formed through two main means: electronic communication (mainly Facebook and emails) thanks to some archival research on the Internet, and 'word of mouth', whereby potential participants would be informed and asked by mediators about participating in the study. After I presented a preliminary version of this paper (based on twelve interviews) in the International Indigenous Research Conference, Ngā Pae o Te Māramtanga, Auckland, (15-18 November, 2016), I connected with four more participants. I located three other participants through connections with community members in the Auckland Hebrew Congregation, and one participant came through my request on the local social online networking ('Neighbourly').

To protect my participants' privacy, I am unable to report their iwi affiliations. However, I am able to say that they are from various iwi in the North Island. Their Jewish ancestry is mainly Ashkenazi (England, Germany and Poland), apart from two participants with Sephardi ancestry (Syria and Turkey). Some informants reported intermarriage with regard to eight generations ago, others reported intermarriage five generations ago, and others still have intermarried grandparents or parents (two to three generations). In some cases, intermarriage between Māori and Jews occurred more than once in their whakapapa. Overall, the ages of the participants ranged from eighteen to sixty-nine years old at the time of this study, encompassing three generations. This age range enabled me to examine any distinct characteristics and similarities between the generations.

The participants reside mainly in Auckland, with the exception of one woman who is currently dividing her life between two countries. Sixteen participants of the twenty-one are tertiary educated with an assortment of degrees, while the women are considerably more educated than men. In accordance with this high level of tertiary education, the participants are mainly professionals in the arts, health and education. Nearly all of the participants owned a house or an apartment or resided in a family-owned home.

Some participants were reluctant to participate in the study because they dreaded being confronted with the limitations of their knowledge in Judaism and/or Māoridom. ${ }^{3}$ Often upon my reassurance that apart from being able to identify Jewish and Mãori ancestors in their linages, there were no criteria for how Jewish or Māori they are, they became thrilled to tell me their stories and memories. Knowing I am Jewish and Israeli as well as a New Zealander 
who speaks Hebrew, and that I was learning Te Reo Māori, encouraged some participants to talk about their paths, and their knowledge of the languages. In other cases, I felt that people eagerly anticipated an opportunity to tell their memories, delighted to have been asked. In many cases, serendipity struck and the participants had just begun researching their whakapapa and asking about unexplored issues, at the same time as I invited them to participate in the study. Therefore, several of the participants saw the study as a personal sign or an omen that they were on the right track of reconnecting with their whakapapa; it was time for them to approach certain unresolved issues, reach closure, and in some cases pay homage to their ancestors, or even visit Israel.

In the next section I move to their memories and experiences, focusing on the practices they enact with regard to funerals and food.

HOME AS AFFECTIVE INFRASTRUCTURE: MEMORIES OF INTIMACY WITH ANCESTRY

Māori Jewish funerary practices are related to cosmological understanding and whakapapa, expressing how intimacy with ancestors from two main cultures is negotiated at this highly intense crossroad in the lives of whānau; a juncture which might also pronounce ambivalence and racial tensions. Hence, tangihanga (meeting of 'crying') or in short 'tangi' (cry) is often used to resolve disagreements, and showcase cohesion and solidarity in the face of adversity, while also giving room for innovation (Edge and Nikora 2010; Nikora et al. 2010; Sinclair 1990). As shall be seen, through this powerfully ritualised memory Māori Jews express the culmination of emotions, as well as funerary Jewish costumes and practices that scaffold Māori structure and content, rather than shake or destroy tikanga (tradition).

\section{Memories of funerary practices}

'I like to say that my Jewish and Māori ancestors have my back, I carry them on my back'. Referring to funerary practices, a twenty-five year-old Māori Jew who literally carried on his back his relationships with his ancestors. He explained that Ta Moko (traditional tattoo) on the right side of his neck, descending toward his back, represents his 'strong and loud' Māori maternal grandparents, and the left side of his neck descending toward his back, represents his 'modest and patient' Jewish paternal grandparents. Despite the 'racism' he endured during his Jewish grandfather's funeral from his cousins, as he was not permitted to carry the coffin for not being 'fully Jewish', he attested that the connection to his Māori and Jewish ancestors and their memory is what makes him different 
to other Māori and a unique individual. This sense of difference was described with ambivalence by Māori Jews. Growing up in his family's home, a fifty-one year-old man said that he felt equally connected to both cultures or as he put it: 'This thing - being Māori and Jewish, an awareness of being an exception'. He expressed this awareness of being different to other Māori and a unique individual with some self-irony when he stated that 'funerals get weird in my family'.

Yet this was the case in the funerals of most of the participants' ancestors. As a sixty-two year-old woman said: '[Our funerals are] unconventional but feel appropriate to us'. She described her two brothers' funerals by saying:

When he died, we had a tangi for him at our marae. When we closed the lid on his coffin we put his yarmulke (head cover for Jewish males) on his head. One of the members of the Jewish community also said prayers at the graveside along with the Anglican priest who officiates at the marae. When my other brother was in hospital and only had days to live, he was asked whether he wanted a priest. He said he wanted a rabbi. There is no rabbi in our city, but the hospital called a member of the local Jewish community who makes himself available in these situations. He came and stayed with us for most of that time until my brother died. He made sure his eyes and mouth were closed and said a prayer. This brother also had a tangi at our marae, and it was agreed that this community member should also attend the service on the day of his burial, and officiate alongside one of our kaumatua [elder] who often officiates as an Anglican priest. So some of our funerals have had mixed traditions.

Another example of how the mixed traditions are remembered and practiced at this crossroad was raised by a fifty-one year-old woman who described her mother's funeral as first following the Jewish tradition of cleansing the body and wrapping it in white cloth. Then, after some deliberations, her mother's body was wrapped up in 'korowai' (Māori cloak) before the body was lowered into the grave. In her grief after the death of her parents, this woman told of severe depression. She felt she had to 'strip off' her cultures when depressed in order to start fresh and cope with racial tensions. In our conversation the cloak became the metaphor for 'wearing your culture again' as a source of comfort that supported her improving health. She was 'remembering how to live with these memories', and this led her to plan a trip to Israel.

Following our interviews, I met with two participants at the Jewish cemetery in Karangahape Road (Auckland central). They wished to visit the graves of 
their Jewish ancestors for the first time, conjoining Māori and Jewish funerary practices. Already before their entry, and then again upon departing the cemetery, they sprinkled water over themselves for purification, as Māori do. One participant, who happened to carry a special stone from the burial place of her Māori ancestor in Northland, placed it on the grave of her Jewish ancestor, following my suggestion and the Jewish practice that was unbeknown to her. She rejoiced that she was able to re-join their memory and spirits through her actions and remembrance, articulating a moment of reconciliation of racial tension within her whakapapa. Similarly, on an organised visit to their ancestor's grave with several people from another participant's whanau following his interview, this practice was extended so that visitors who were part of the whanau were happy to both sprinkle water and place a stone. For another woman, the mere act of cleaning the gravestones and revealing Māori writing on the grave of a Jewish ancestor provoked a sense of intimacy with that ancestor. She was happy of recovering that missing link in her whakapapa, which she articulated by saying that her 'Jewish ancestor took on the Māori culture'. She proudly sent me a photograph of the writing on his gravestone, which said: (1893-1894) 'HE TUHO AROHA TENEI MO... ME ORAUA URI KUA MATE' (The love for him is steep... from the descendants of the deceased), along with his Jewish name in Māori.

Typically since the Jewish parent expressed strong affinity, affection and familiarity with the Māori culture of their spouse while living, the family followed Māori tangihanga with Jewish elements in burial. As one woman whose Jewish father and Māori mother passed away put it:

I mean dad was always cheerful, and he was always lovely, my dad, he was a very gentle person [... ] It's interesting, when Mum died we had the Māori ceremony. But when Dad died we had a tangi for him as well: we took him to our marae, because he is well known where I grew up, because... he had a lot to do with the Māori community, and Mum too. He spoke fluent Māori and taught Māori [ ... ] when he passed away, one of his Jewish cousins came to the tangi [ ... ] so for Dad we had half of it in Jewish [Hebrew] and half of it in Māori. And the children, I organised for the children to - all the mokopuna to take the service, and Dad's cousin provided words for the children to say, from, he had, not a lot in Jewish, but he had this particular book [Siddur, Jewish prayers book]. And then we had Māori as well.

And the other thing is when we had the stone, you know we have the memorial service a year later, and the stone is unveiled, we got Jewish 
words on the stone that Dad liked..., and since we are not allowed to put flowers or anything on Dad's grave, so all the grandchildren put stones, decorated stones, and my sisters too, and they are still there. He died in 2010, and I go back home, I have got the family house, so I go back a lot, and always go back and make sure they are still in the same place... The paint has faded on some of them, but the stones are still there... Some are pebbles, just little, not great big stones, and they just painted on them.

In contrast to this narrative steeped with longing for her dead parents and the intimacy expressed in this remembering, mamae (pain) and pouri (grief) were both expressed in the memories of a fifty-three year-old man whose kin deeply missed the Jewish ancestor in their Māori whakapapa. Eight generations ago this Jewish ancestor was expelled from the Māori iwi he married into for unknown reasons, returning to New South Wales, Australia. His full name was lost from the whakapapa, including the names of his children, details of their lives, death and burial places. Ten years ago this man married a Jewish woman and together they had a son. This man saw the birth of his son as the resurgence of the Jewish line in his Māori whakapapa.

The excerpts above show that memories of funerary practices convey intimacy that raises some racial tension, which can be overcome by reaffirming affiliation with the mixed racial whakapapa in an attempt to reach reconciliation. Often the case is that the Māori whānau provide the 'warmth' and 'embrace' that the Jewish families withdraw, to paraphrase several of the participants. Connections with ancestry are strong in both cultural traditions and can provide bedrock of well-being once reaffirmed, as the example above shows.

The memories of my participants converge on complementing fundamental principles in both Māori and Jewish cultures. The fundamental Māori principle of remembering ancestors is aptly put by the renowned Māori Pākehā author Witi Ihimaera $(2014,16)$ as:

[...] a particular way of looking at the past as something that doesn't lie behind us but is in front of us; that goes for the ancestors, too, not comfortably dealt with and consigned to the past tense but watching over us and still waiting to be accounted to. Another way of viewing this phenomenon is to say that Mãori walk backwards into the future. All those ancestors sitting in the room behind our eyes walk along with us, too. 
The fundamental Jewish principle of remembering ancestors is summed up by the saying: 'Know where you come from, and where you are going to...,' and in one of the oldest and most important meanings for the word 'home' (bayit) in Hebrew, your tribal connections.

\section{Food and commensality as the structure of intimacy}

The domain of food is part of the tangi as hākari (feast), and complements the discussion in funerary practices. Food signifies life and the connection with whakapapa as another means to embody intimacy. Food is another ordinary yet fundamental domain that prevailed in the memories of the participants, signifying the everyday connections with whakapapa, and sometimes marrying the Jewish and Mãori cultures in humorous ways. For example, a forty-two year-old woman remembered her mother's cravings for matzah - the big, dry 'Jewish crackers' of unleavened bread for Passover (Jewish festival). In addition, she remembered her mother's love for baking 'pakipaki' (buns) and her making Māori fried bread on other occasions. Rather than sliced, she would only allow the 'pakipaki' to be torn by hand, as is done with challah (bread) during the Kiddush (ceremony) that welcomes the Shabbat (the day of rest). Her maternal Jewish grandfather was an expert baker who survived World War Two thanks to his vocation, and her connection with him was formed by and expressed through baking in particular. She remembered his dedicated baking that he would transport around the city of Auckland in his car, delivering to his Jewish customers on Fridays and Jewish festivals. These positive memories stood alongside her negative memories of his racism, which I discuss in the next part.

Another twenty-five year-old woman attested that she is a hui hopper: a person who moves from one hui (social gathering for the purpose of discussion) to another to share kai (food)'. Like the other participants she regarded the deep love for breaking bread with family and guests, cooking, eating and feeding others as important ways of being both Māori and Jewish. This was even more true when a fifty-one year-old man decided to re-enact his affiliation to Judaism to overcome a life crisis in his forties, and 'make a fresh start' through converting to Judaism. A long-time vegan, he did not need to change his eating habits to maintain Kashrut (the Jewish dietary laws). However, upon his conversion he was reminded that his Jewish grandmother tithed the dough when baking bread for Shabbat and his grandfather would say Jewish prayers when butchering meat. He remembered that his grandfather could not stand butter on his bacon sandwich, due to the Jewish prohibition of mixing meat with dairy, completely ignoring the prohibition of eating pork. A sixty-three year-old woman remembered that her mother used to bake challah and a spe- 
cial Passover chocolate cake, typically using almond meal instead of flour. This cake was her mother's cherished 'secret family recipe' and is still being baked for Christmas. Conversely, remembering her mother's cooking, another fifty-three year-old woman suggested that apart from her Polish-Jewish chicken soup, all she cooked was Māori food, including baking rewena (Māori potato bread), also preparing preserved seaweed which needed to dry for three months. She fondly remembered her childhood when eating the seaweed in a cup mixed with butter and boiling water, and sharing this experience with her siblings.

Indeed, baking and food by extension are very important ways of learning to be Māori and Jewish that most participants remembered from their childhood. Previous research on Māori cooking during the 1970s cultural renaissance showed that the Mãori culinary tradition has been maintained despite colonisation and technological changes (Leach 2010, 52-53). This study also highlights the place of baking, which my participants remembered when conveying intimacy in their relationship with parents and grandparents. By remembering commensality, eating home baked goods amongst family and friends, they also manifested the bakers' hospitality and mana. As one woman put it, 'My nana always had her tins full of exquisite biscuits, and I loved her baking. I did not know that baking was Māori or Jewish, and as a child I thought that this was the same with all nanas'.

\section{Racial tension in the whānau}

The participant thought that had her youngest sister and herself been born with darker skin, her Jewish grandmother's love would have been different, although her racism is obvious, especially since she knows what her Jewish grandmother thinks and how she feels toward her Māori mother (interview summary with twenty-one year-old woman).

Most of the participants experienced first-hand intergenerational racism within their kin networks. As the excerpts above suggest, racism might take explicitovert or implicit-covert forms, yet in any case is felt most deeply. For example, three participants said their Jewish grandparent repeatedly told their Māori parent to ' go back home'. In their case, the undesired tension between the grandparents and grandchildren contrasted with the endearing relationships that are accounted by Salmond and Metge in Gagnés description $(2013,117-123)$ as the most common type of relationship between tūpuna (ancestors or family relations of older generation) and mokopuna (grandchildren). In these three cases, the Jewish grandparent's attitude cast a shadow on the kinship relation- 
ships to the extent that these three participants said that they did not feel like they 'had a grandparent' or that their grandparent was always 'angry' and did not 'know how to love'. As adults they expressed love, respect and pride toward their Māori parent to counterbalance this racism, and their sense of exclusion and denigration.

For many of the participants, intimate memories of their Māori whakapapa became a drive to succeed as Māori. For example, recent family strife between the Jewish mother and the Māori father, a friction that occurred over the father's high monetary and affective involvements in a treaty claim, caused one woman to refer to her Jewish ancestors critically. To overcome this bad blood, the woman, like most of the participants who could 'pass' as Pākehā thanks to fair skin, repeatedly pronounced and reinstated her Māoriness. This woman specifically used fond and nostalgic memories of the time that her mother 'behaved like a Māori', as other participants with a Jewish parent commonly did. She remembered with joy and sorrow how her mother immersed herself in the Māori culture; cooking Māori food at home and helping to cook in marae gatherings, using Te Reo Māori expressions, and helping out with her mokopuna on a daily basis.

Racial tension in the whānau and the relations with grandmothers is exemplified by the simple yet profound words of the late Mahingārangi Tocker, a Māori Jewish singer-songwriter and political activist. In her unique 1997 album, Te Ripo (the flow) she sings a Song to Nana and Kui (her Jewish and Mãori grandmothers respectively).

... Nana was it hard... was it hard... shalom... shalom... shalom... your son married away from home... your son married my mother / e kui (grandmother) I heard your call on this trembling earth / e kui I felt your life when I gave birth / thank you for my name but are our memories going to be the same? / was it hard for you that our bones have changed / e kui was it hard / korero mai (talk to me) your daughter married away from home / your daughter married my father / I'm not as black as Hinekekehu / I'm not as pale as Vera... / but my parents have taught me well and I am as proud as they are...

Tocker's words show clearly how racial tension in 'marrying away' is experienced, internalised and then overcome by herself as a granddaughter and a mother. The mention of the skin colours of the Māori and Jewish grandmothers, 'black' and 'pale' respectively, reiterates the tension expressed by the question 'was it hard for you that your bones have changed'. But her pride in her mixed 
racial heritage overrides this tension, taking a course that sums up the emotions expressed by all the participants in this study.

Integrating Berlant's (1998) theory on how affective paradoxes at home feed into the public domain and vice versa with the notion of nostalgia as expressing defiant memory (Berdahl 2008; Spitzer 1999), it is evident that tension in the memories of Māori Jews reflectsMāori Pākehā power relations in New Zealand society at large. As Māori Jews resist and challenge racist attitudes and behaviours within their whannau they cope with and overcome this racist tension through their defiant memories that critique 'home'. In the first and second sections I have shown that it is memories of intimacy with whakapapa that instigate expressions of their sense of loss, pain and longing for home. I have also shown that it is also intimacy with whakapapa as the lived relationship that drives those pale skinned Māori Jews to identify as Māori and their motivation to succeed through education and vocation despite awareness of the systemic inequalities that become personal obstacles in their paths. Their personal success as such can be seen as an act of cultural recall that defies social failure and benefits the broader Māori community. In the third section I have shown that it is also the memory of intimacy with whakapapa that drives this critique of 'home' as the very social relationship with people and places, and particularly the kinship relationship that make up their sense of belonging by evoking their everyday memories of whānau.

\section{DISCUSSION}

In a special issue of the academic journal Oceania researchers address recent Melanesians claims for strong affiliations with Judaism, Israel and Zionism in Fiji, the Solomon Islands and Papua New Guinea (Brown and Newton 2015). These claims stem from localised interpretations of Christianity, encompassing a myriad of ways such as directly descended from or having a spiritual kinship with patriarchs in Hebrew Scripture (Noah or Moses), or from the 'Lost Tribes' of Israel' (Brown and Newton 2015, 251). As suggested by Silverman (2015) in his commentary, regardless of whether these claims are factual or spiritual and aspirational, it is important to contemplate their overarching objectives from the Melanesian and the Jewish perspectives. In these claims Melanesians critique the current state of affairs in their national homes because of corruption and poverty, at the same time striving for validity and better lives.

This paper illustrates how the twenty-one contemporary Māori Jews in my study employ their memories of funerary practices and the domain of food, dovetailing their Māori and Jewish connections with whakapapa to cope with 
the racial tension within their whannau. They convey intimacy toward their whānau and longing for whakapapa, which are expressed in ritualised and practical everyday ways. In their 'defiant memory' (Spitzer 1999) they also critique their 'home' in references to racial tension as they constitute their own 'infrastructure of intimacy' (à la Lauren Berlant 1998). Their lived relationships with ancestors constitute their political subjectivity, employing defiant memory as a means of resistance to negotiate a sense of being 'at home' in Aotearoa, New Zealand. Knowing that they are both Māori and Jewish is mainly a source of comfort and strength to them, and they are able to use their memories of racial tension as an incentive to look beyond the racial divides. Thus their defiant memory not only articulates the complexity of affective contradictions of longing and ambivalence toward home, but also attests to their resilience and hopes.

The idea of 'home' as a multidimensional space that is reconstituted by memories that express contradicting emotions in this paper focuses on the dimension of ancestral-familial connections with whakapapa that expresses kinship relationships. The great importance of whakapapa as remembered and lived relationship that make up a feeling of being 'at home' is supported by previous research that highlights affirmative identities, success and a sense of security for Māori groups (Doerr 2015; Houkamau 2011; Tamaira 2007; Te Rito 2007; Webber 2008, 2011).

The understanding of 'home' as a multidimensional space that is negotiated through memories, expressing contradicting emotions in relation to the dimension of ancestral-familial connections is a key for understanding how and why people critique home. This is suggestive of the Melanesian critique of 'home' as a means of contesting inequity and expressing hopes for better well-being. As in the case of Māori Jews, the notion of well-being is not only conceived individually and collectively (or nationally), but is a continuous reality that derives from remembering ancestral pasts and negotiating racial tension to foster success.

\section{CONCLUSION}

In this paper I demonstrated how both affective expressions of intimacy and critique toward home in memories of whakapapa by Māori Jews realise their lived relationships and impact their well-being. I have shown that contemporary Māori Jews employ their defiant memory to constitute the infrastructure of intimacy in their ancestral-familial homes to cope and deal with racial tension, expressing their critique in hopes for better future. It is my hope that future research would look into other dimensions of home and domains of 
remembering to better understand how Māori and other indigenous groups in the world employ their memory to deal with societal tensions.

\section{ACKNOWLEDGMENT}

I am grateful for the recognition and the award I received from the Kate Edgar Educational Charitable Trust, the Dame Joan Metge Post-Doctoral award (2016) to conduct this study. I am also grateful for the opportunity to present a preliminary version of this paper at the International Indigenous Research Conference, Ngā Pae o Te Māramtanga, Auckland, 15-18 November. I am indebted to my supervisor Dr Carla Houkamau who has supported this study since inception. I am forever thankful to the strangers who shared their memories and lives with me by participating in this study. Finally, my gratitude goes to those who read various drafts of this paper and made their invaluable comments.

\section{NOTES}

1 Dr Hadas Ore is a social anthropologist trained in Israel and Aotearoa, New Zealand. In 2016 Dr Ore won the Joan Metge post-doctoral award by the Kate Edgar Educational Charitable Trust to conduct the first research on the memories of Māori Jews under the guidance of Dr Carla Houkamau in the University of Auckland, The Business School. Dr Ore teaches Hebrew in Kadimah School, the only Jewish day school in Auckland. Dr Ore is an independent researcher and publishes academically in the anthropology of home, memory, nostalgia, food, migrants and gender.

Email: hadaso@kadimah.school.nz or horeoo3@aucklanduni.ac.nz

2 There is statistical data on 1463 Jews who belong to 'the Hebrew church' in 1893. This number is measured against the whole population and shown to be in decline - from o.34 per cent in 1878 to 0.23 per cent in 1891 (Yearbook 1893). Based on 2013 New Zealand census, the Israeli/Jewish ethnic group comprised 1,353 people or less than one per cent of the people that stated an ethnic group living in Aotearoa, New Zealand (Statistic New Zealand 2013, http://www.stats.govt.nz/ Census/2013-census/profile-and-summary-reports/ethnic-profiles.aspx?request_ value $=24768$ \&parent_id=24761).

3 Ambiguity is inherent in defining who is Jewish, as this classification may relate to religious, ethnic, racial and cultural affiliations. Regarding the question of 'who is Jewish', the Israeli state's laws follow maternal bloodline according to Jewish Halachic laws, and Jewish orthodoxy for conversion into Judaism (Silverman, 2015). 
4 This understanding is based on a very well-known and ancient moral saying from Pirkei Avot, Ethics of the Fathers, chapter three, in the order of Nezikin in the Mishnah (dated at least to $200 \mathrm{BCE}$ ).

\section{REFERENCES}

Aikman-Dodd, Pounamu Jade William. 2013. From Subcontinent to Subtropical: Indian-Māori Relationships in Aotearoa/New Zealand. Postgraduate students funded by the Asian Migrations Research theme. Otago University. Accessed 21 April 2016 from http://www.otago.ac.nz/asianmigrations/postgraduateresearch/otagoo63681.html

Armove, Sabrien. 2017. 'Homes as Infrastructures of Intimacy'. Space and Society. Accessed 18 August, 2018 from http://societyandspace.org/2017/10/03/homesas-infrastructures-of-intimacy/

August, Wikitoria. 2005. 'Māori Women: Bodies, Spaces, Sacredness and Mana'. New Zealand Geographer 61(2):117-123.

Bailey, Carrie. 2012. An Annotated Bibliography of Information Resources Chronologing the Jewish Experience in New Zealand, Victoria University of Wellington, School of Information Management. http://researcharchive.vuw.ac.nz/xmlui/ handle/10063/2515

Bardenstein, Carol. 2002. 'The Gender of Nostalgia, Transmissions Interrupted: Reconfiguring Food, Memory, and Gender in the Cookbook-Memoirs of Middle-Eastern Exiles'. Signs 28 (1):353-387.

Battaglia, Debborah. 1995. 'On Practical Nostalgia: Self-Prospecting among Urban Trobrianders'. In Rhetorics of Self-Making, edited by D. Battaglia, 77-96. Berkeley and Los Angeles: University of California Press.

Beaglehole, Ann. 2013. Refuge New Zealand: A Nation's Response to Refugees and Asylum Seekers. Dunedin: Otago University Press.

Beaglehole, Ann, and Hal B. Levine. 1995. Far from the Promised Land?: Being Jewish in New Zealand. Wellington, New Zealand: Pacific Press.

Bell, Leonard, and Diana Morrow. 2012. Jewish Lives in New Zealand: A History. Godwit. 
Berdahl, Daphne. 2009. On the Social Life of Postsocialism: Memory, Consumption, Germany, edited by Matti Buntzl. Bloomington, Introduction xiii-1, Indiana: Indiana University Press.

Berlant, Lauren. 1998. 'Intimacy: A Special Issue'. Critical Inquiry 24 (2):281-288.

Blank, Anton, Carla Houkamau, and Hautahi Kingi. 2016. Unconscious Bias and Education: A Comparative Study of Māori and African American Students. Oranui Diversity Leadership.

Bozic-Vrbancic, Senka. 2004. Celebrating Forgetting: The Formation of Identities and Memories by Tarara in New Zealand. Anthropology, University of Auckland, Auckland, Ph.D.

Brown, Terry, M., and Lynda Newland. 2015. 'Introduction: Descent from Israel and Jewish Identities in the Pacific, Past and Present'. oceania Special Issue: Descent from Israel: Jewish Identities in the Pacific, Past and Present. 85(3): 251-255.

Callister, Paul. 2003. 'Māori/Non-Māori Ethnic Intermarriage’. New Zealand Population Review 29 (2):89-105.

. 2008. 'Skin Colour: Does it matter in New Zealand?' Policy Quarterly $4(1): 18-25$.

Came, Heather. 2014. 'Sites of Institutional Racism in Public Health Policy Making in New Zealand'. Social Science and Medicine 106 :214-220.

Carter, Lynette. 2015. “Iwi, Are Where the People Are”. Re-thinking Ahi Kā and Ahi Mātao in Contemporary Māori Society’. In Home: Here To Stay, edited by Marilyn McPherson and Liniatā Manu'atu Mere Kepa, 23-32. Wellington Aotearoa New Zealand: Huia Publishers.

Chapple, Simon, and David Rea. 1998. 'Time Series Analysis of Disparity between Maori and Non-Maori Labour Market Outcomes in the Household Labor Force Survey'. Labor Market Bulletin, 12:127-44.

Creighton, Millie. 1997. 'Consuming Rural Japan: The Marketing of Tradition and Nostalgia in the Japanese Travel Industry’. Ethnology 36 (3):239-254.

Cunningham, Chris. 20o8. 'Diversity and Equity for Māori'. In Understanding 
Health Inequalities in Aotearoa New Zealand, edited by Kevin Dew and Anna Matheson, Dunedin, New Zealand: Otago University Press 55-66.

Doerr, Neriko Musha. 2015. "II Have Māori in Me”: Shades of Commitment and Negotiation of Subjectivity in an Aotearoa/New Zealand School'. Ethnos 8o (2): 168-191.

Duruz, Jean. 1999. 'Food as Nostalgia: Eating the Fifties and Sixties'. Australian Historical Studies 29 (113):231-250.

Edge, Kiri, and Linda Waimarie, Nikora. 2010. Dual Cultural Identity and Tangihanga: Conflict, Resolution and Unexpected Outcomes. Paper read at Proceedings of the 4 th International Traditional Knowledge Conference, at Auckland, New Zealand.

Gagné, Natacha. 2013. Being Māori in the City: Indigenous Everyday Life in Auckland. Toronto, Buffalo, London: University of Toronto Press.

Gluckman, Ann. 1990. Identity and Involvement: Auckland Jewry, Past and Present. Palmerston North, New Zealand: Dunmore Press.

Goodyear, Rodney. 2009. The Differences Within, Diversity in Age Structure Between and Within Ethnic Groups. Wellington: Statistic New Zealand.

Hage, Ghassan. 1997. 'At Home in the Entrails of the West: Multiculturalism, "Ethnic Food" and Migrant Home-Building. In Home/World: Space, Community and Marginality in Sydney's West, edited by Helen Grace, 99-153. Annandale, NSw: Pluto Press.

Hippolite, Holly Raima, and Toni Bruce. 2010. 'Speaking the Unspoken: Racism, Sport and Māori'. Cosmopolitan Civil Societies: An Interdisciplinary Journal 2(2): $23-45$.

Houkamau, Carla A. 2011. 'Transformations in Māori Women's Identity: Some Things Change, Some Stay the Same'. Qualitative Research in Psychology $8(3): 292-313$.

Houkamau, Carla A., and Chris G. Sibley. 2011. 'Māori Cultural Efficacy and Subjective Wellbeing: A Psychological Model and Research Agenda'. Social Indicators Research: An International and Interdisciplinary Journal for Qualityof-Life Measurement 103 (3):379-398. 
- 2014. 'Social Identity and Differences in Psychological and Economic Outcomes for Mixed and Sole-Identified Māori'. International Journal of Intercultural Relations 40:113-125.

- 2016. Cultural Connection Predicts Perceptions of Financial Security for Māori.' Social Indicators Research: An International and Interdisciplinary Journal for Quality-of-Life Measurement 133(1):395-412.

Houkamau, Carla A., Samantha Stronge, and Chris G. Sibley. 2017. 'The Prevalence and Impact of Racism toward Indigenous Māori in New Zealand'. International Perspectives in Psychology: Research, Practice, Consultation 6 (2): 61-80.

Ihimaera, Witi. 2014. Māori Boy: A Memoir of Childhood. Auckland, New Zealand: VINTAGE.

Ip, Manying. 2008. Being Māori-Chinese: Mixed Identities. Auckland: Auckland University Press.

- 2009. The Dragon and the Taniwha: Mäori and Chinese in New Zealand. Auckland: Auckland University Press.

Johnston, Patricia, and Leonie Pihama. 1994. 'The Marginalisation of Māori Women'. Hecate 20 (2): 83-97.

Kugelmass, Jack. 1990. 'Green Bagels: An Essay on Food, Nostalgia, and the Carnivalesque'. Yıvo Annual of Jewish Social Science 19:57-80.

Law, Lisa. 2005. 'Home Cooking: Filipino Women and Geographies of the Senses in Hong Kong. In Empire of the Senses: The Sensual Culture Reader, edited by David Howes, 224-244. Oxford; New York: Berg.

Leach, Helen. M., ed. 2010. From Kai to Kiwi Kitchen: New Zealand Culinary Traditions and Cookbooks. Dunedin: Otago University Press

McDermott, Sinead. 2002. 'Memory, Nostalgia, and Gender in A Thousand Acres'. Signs $28(1): 389-407$.

Morris, Carolyn. 2010. 'The Politics of Palatability On the Absence of Māori Restaurants'. Food, Culture and Society: An International Journal of Multidisciplinary Research 13 (1):5-28. 
Muriwai, Emerald, Carla A. Houkamau, and Chris G. Sibley. 2015. 'Culture as Cure? The Protective Function of Māori Cultural Efficacy on Psychological Distress'. New Zealand Journal of Psychology 44 (2):14-24.

Nikora, Linda Waimarie, Ngahuia Te Awekotuku, Mohi Rua, Pou Temara, Te Kahautu Maxwell, Enoka Murphy, Karyn Okeroa McRae, and Tess Moeke-Maxwell. 2010. Tangihanga: The Ultimate Form of Māori Cultural Expressionoverview of a Research Programme, edited by The University of Waikato. Auckland, New Zealand: Ngā Pae o te Māramatanga.

Ore, Hadas. 2015. 'Can home come in a tin can?': How Jewish-israeli Migrant Women Savour Home in New Zealand, Anthropology, The University of Auckland. PhD.

Pack, Sylvia, Keith Tuffin, and Antonia Lyons. 2016. 'Accounts of Blatant Racism Against Māori in Aotearoa New Zealand'. sites: A Journal of Social Anthropology and Cultural Studies 13 (2): 85-110.

Pio, Edwina. 2009. Cast Away? Unfolding the Māori Indian, edited by The Office of Ethnic Affairs. Wellington, New Zealand: The Office of Ethnic Affairs.

Puckey, Adrienne 2006. The Substance of the Shadow: Māori and Pākehā Political Economic Relationships 1860-1940 - A Far Northern Case Study, History, The University of Auckland. M.A. Thesis.

- 2011. Trading Cultures: A History of the Far North. Wellington: Huia Publishers.

Roberts, Mere, Bradford Haami, Richard Anthony Benton, Terre Satterfield, Melissa L Finucane, Mark Henare, and Manuka Henare. 2004. 'Whakapapa as a Māori Mental Construct: Some Implications for the Debate over Genetic Modification of Organisms. The Contemporary Pacific 16 (1):1-28.

Rose, Paul. 2009. Ngati Hebrew: Stories of the First Jewish Settlers in New Zealand. Auckland: PRмB Books.

Rosenthal, Odeda. 1988. Not Strictly Kosher: Pioneer Jews in New Zealand. Wainscott, New York: Starchand Press.

Sibley, Chris G., Niki. Harré, William. James. Hoverd, and Carla Anne. Houkamau. 2011. 'The Gap in the Subjective Wellbeing of Māori and New Zealand Eu- 
ropeans Widened Between 2005 and 2009' Social Indicators Research: An International and Interdisciplinary Journal for Quality-of-Life Measurement 104(1):103-115.

Sibley, Chris G, James H Liu, and Sammyh S Khan. 2008. 'Who are "we"? Implicit Associations between Ethnic and National Symbols for Maori and Pakeha in New Zealand'. New Zealand Journal of Psychology 37 (2):38-49.

Silverman, Erik. 2015. 'Commentary: Modernism, Jews, and Frazer' ocEANIA Special Issue: Descent from Israel: Jewish Identities in the Pacific, Past and Present. $85(3): 359-375$

Sinclair, Karen. P. 1990. 'Tangi: Funeral Rituals and the Construction of Maori Identity'. In Cultural Identity and Ethnicity in the Pacific, edited by Joycelyn Linnekin and Lynn Poyer, 219-236. The United States: University of Hawai' 1 Press.

Spitzer, Leo. 1999. 'Back Through the Furture: Nostalgic Memory and Critical Memory in a Refuge from Nazism'. In Acts of Memory: Cultural Recall in the Present, edited by Mieke Bal, Jonathan. Crewe and Leo. Spitzer, 87-104. Hanover and England: University Press of New England.

Statistics New Zealand Yearbook. 1893. Yearbook Collection: Tatauranga Aotearoa. 1893-2012. Accessed 13 August 2018 from http://www.stats.govt. $\mathrm{nz} /$ Census/2013-census/profile-and-summary-reports/ethnic-profiles. aspx? request_value $=24768 \&$ parent_id $=24761$

Sugiman, Pamela. 2005. 'Memories of Internment: Narrating Japanese-Canadian Women's Life Stories'. In Diaspora, Memory and Identity: A Search for Home, edited by Vijay Agnew, 48-80. Toronto: University of Toronto Press.

Sylvia Pack, Keith Tuffin, and Antonia Lyons. 2017. 'Resisting Racism: Māori Experiences of Interpersonal Racism in Aotearoa New Zealand'. AlterNative: An International Journal of Indigenous Peoples 11 (3):269-282.

Tamaira, Moata Nicola. 2007. Searching for Tūpuna: Whakapapa Researchers and Public Libraries, The School of Information Management, Victoria University of Wellington, MA Thesis.

Te Rito, Joseph. 2007. 'Whakapapa: A Framework for Understanding Identity'. MAI Review: Ngā Pae o te Māramatanga 2:1-10. 
Wanhalla, Angela. 2008. “One White Man I Like Very Much”: Intermarriage and the Cultural Encounter in Southern New Zealand, 1829-1850'. Journal of Women's History $20(2): 34-56$.

- 2009. In/visible Sight: The Mixed-Descent Families of Southern New Zealand. Wellington: Bridget Williams Books.

- 2013. Matters of the Heart: A History of Interracial Marriage in New Zealand. Auckland, New Zealand: Auckland University Press.

Webber, Melinda. 2008. Walking the Space Between: Identity and Māori/Pākehā. Wellington, New Zealand: Nzcer Press.

- 2011. Identity Matters: Racial-ethnic Representations Among Adolescents Attending Multi-ethnic High Schools, The School of Education, The University of Auckland, Auckland.

Wigglesworth, Roger. 1990. 'Montefiore, John Israel', Dictionary of New Zealand Biography. In Te Ara - the Encyclopedia of New Zealand.

Williams, Herbert Williams. 1957. A Dictionary of the Maori Language, Sixth Edition. Wellington, New Zealand: Government Printer. Accessed 25 August 2018 from http://nzetc.victoria.ac.nz/tm/scholarly/tei-WillDict-t1-front-d7.html 